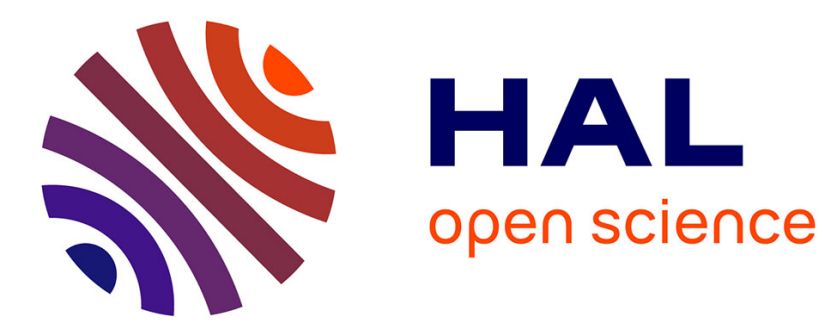

\title{
Legitimation process in organizations and organizing: An ontological discussion
}

François-Xavier de Vaujany

\section{To cite this version:}

François-Xavier de Vaujany. Legitimation process in organizations and organizing: An ontological discussion. Materiality in Institutions: Spaces, Embodiment and Technology in Management and Organization, In press. halshs-01840927

\section{HAL Id: halshs-01840927 https://shs.hal.science/halshs-01840927}

Submitted on 16 Jul 2018

HAL is a multi-disciplinary open access archive for the deposit and dissemination of scientific research documents, whether they are published or not. The documents may come from teaching and research institutions in France or abroad, or from public or private research centers.
L'archive ouverte pluridisciplinaire HAL, est destinée au dépôt et à la diffusion de documents scientifiques de niveau recherche, publiés ou non, émanant des établissements d'enseignement et de recherche français ou étrangers, des laboratoires publics ou privés. 


\title{
Legitimation process in organizations and organizing:
}

\section{An ontological discussion ${ }^{1}$}

\author{
François-Xavier de Vaujany \\ DRM-M\&O (UMR CNRS 7088) \\ PSL, Université Paris-Dauphine \\ devaujany@dauphine.fr
}

\begin{abstract}
Legitimacy and legitimation are key topics of the management literature. In the 70s and 80 s, legitimating mainly meant convincing and sticking to the rules of a dominant external stakeholder (with a stable set of preferences) that needed to be convinced. Today, other processes have emerged. They are more based on the crowd-based, communitygrounded, value co-creation oriented, and take the shape of big emotional waves pushed by an infinite sum of small generosities. In short, they are more de-centered. If the bulk of institutional concepts are powerful to explain the first situation (which still remains present), the latter process dynamic requires some revisions and extensions which are detailed here. By means of three ontologies of legitimation, I discuss three processes extending a discursive and judgmental view of legitimation.
\end{abstract}

Keywords: Legitimacy; Legitimation; Ontologies; Materiality; Space; Time; Embodiment.

\footnotetext{
${ }^{1}$ This chapter is based on a keynote delivered at the Asia-Pacific Researchers in Organization Studies (APROS) conference in Sydney (December, 2015) and a further draft presented at the $6^{\text {th }}$ Organizations, Artifacts \& Practices (OAP) workshop in Lisbon (June, 2016). We thank participants of both events for their precious questions and feedbacks about this proposal, in particular Thomas Clark, Candace Jones, Stewart Clegg, Julien Jourdan, Nathalie Mitev, André Spicer, Jeremy Aroles and Ann Morgan-Thomas.
} 


\section{Introduction: Three ontologies to describe legitimation processes in the MOS literature?}

Current societal and organizational transformations have made legitimacy a key stake (Dowling and Pfeffer, 1975; Suchman, 1995; de Vaujany and Vaast, 2016). More than ever, legitimacy is evolving and questioned. As people are more and more informed, reflexive and involved in digital tools (thus increasing their connectivity but also the disembodiment of sense-making (Hayles, 1999)), institutions are questioned for the very reasons which made them institutional (i.e. their age and the tradition(s) to which they correspond) and in that context, legitimacy needs to be put into perspective with space and time. More than ever, it needs to be narrated, maintained, re-created, re-enacted, re-spatialized and performed in different ways. It needs to be seen as a more or less harmonious activity or set of activities involving changing human and non-human entities.

The contemporary search for finance and funding epitomizes these trends. Forty years ago, most attempts to finance a project or a new business venture were focused on strong external stakeholders and how to convince them. A bank, a major investor and a group of stakeholders would be involved in a legitimation process. Today, crowdfunding has considerably changed this process (Allison et al., 2015; Bouncken, Komorek and Kraus, 2015; Manning and Bejarano, 2017). The inclusion or exclusion of the stakeholders, the variety and versatility of preferences and criteria along with the nature of the process of achieving legitimacy (for example, through a crowd that may be more emotionally involved through its small contributions as compared to a major stakeholder in its rationally calculated 'investment') have made legitimation itself more open, more emotional and more problematic with regards to its own temporalization and spatialization. More than ever, sense making is decentered (Introna, 2018). Key stakeholders are everywhere or nowhere. They can inhabit any temporality. Beyond the specific example of crowdfunding, the fragmentation and the explosion of the time-space of organizing and work practices (Kallinikos, 2003; Halford, 2005) make it increasingly difficult to identify a stakeholder or group of stakeholders outside and before investment, with a stable mode of cognition and a predefined set of preferences. 
The institutional literature, however, remains largely centered, discursive, cognitive and judgmental in its approach to legitimation as a process (see in particular the literature review of Bitektine (2011) and his description of the 'process of legitimacy judgement formation'). Legitimation is rarely described as an (embodied) experience constituting a legitimate space and time for those involved in it (Voronov and Vince, 2012; Voronov, 2014; Friedland, 2018). As suggested by Friedland (2018: 515), 'emotion not only mediates the formation and reproduction of institutions, but is sometimes itself institutional'. Yet, emotions and their 'here and now' are often absent from the theories and concepts used, in particular in the context of the neo-institutional literature (de Vaujany and Vaast, 2014; Voronov, 2014).

Those are the dimensions and movement that we want to capture here through three ontologies which we see as present or emergent in institutional debates: an 'ontology of discourse' (which stresses the importance of social judgement, rhetoric, discursive structures and their conditions of felicity in the process of legitimation); an 'ontology of sculpture' (which emphasizes the spatial and material dimensions of legitimation but remains partly discursive), and an 'ontology of bubbles' (which departs more radically from a judgmental view of legitimation by including spatial, temporal and pre-reflexive dimensions in the process of legitimation). If for the ontologies of discourse and sculpture, legitimacy remains largely in the eyes of the beholder, the ontology of bubbles locates legitimacy more in the bodies of the beholders. In turn, this implies a more embodied vision of the process of legitimation. For the ontology of bubbles, there is no inside which would need to be aligned with an outside, or a before which would need to be in line with the present. Emotional flow (Merleau-Ponty, 1945) goes beyond these usual boundaries of academic thinking. Our experience of the world involves a shared and common world that is, by itself, emotionally legitimate or a legitimate emotion (see Table 1 below). 


\begin{tabular}{|c|c|c|c|}
\hline & $\begin{array}{l}\text { ONTOLOGY OF } \\
\text { DISCOURSE }\end{array}$ & $\begin{array}{l}\text { ONTOLOGY OF } \\
\text { SCULPTURE }\end{array}$ & $\begin{array}{c}\text { ONTOLOGY OF } \\
\text { BUBBLES }\end{array}$ \\
\hline $\begin{array}{l}\text { Definition of } \\
\text { legitimation }\end{array}$ & $\begin{array}{l}\text { Legitimation is the discursive } \\
\text { process resulting in an } \\
\text { authorized discourse about } \\
\text { something. This authorized } \\
\text { discourse is a text that can } \\
\text { travel in time and space, and } \\
\text { be recursively legitimating. It } \\
\text { can follow various rhetorical } \\
\text { forms that are more or less } \\
\text { legitimating by themselves. }\end{array}$ & $\begin{array}{l}\text { Legitimation is the } \\
\text { interactional process of } \\
\text { alignment between space, } \\
\text { visuals, texts and social } \\
\text { expectations. Actors can } \\
\text { be involved in justificatory } \\
\text { work more or less relevant } \\
\text { for the stakeholders they } \\
\text { need to convince. }\end{array}$ & $\begin{array}{l}\text { Legitimation is the } \\
\text { experience which makes } \\
\text { things emerge self- } \\
\text { evidently, or naturally. The } \\
\text { process is constitutive of } \\
\text { both the thing and its } \\
\text { valuation or presence. }\end{array}$ \\
\hline $\begin{array}{l}\text { of space } \\
\text { le }\end{array}$ & $\begin{array}{l}\text { Space is a context. Time is } \\
\text { out there, a linear and } \\
\text { objective landmark for } \\
\text { legitimacy claims. }\end{array}$ & $\begin{array}{l}\text { Materiality and space play } \\
\text { an active role in legitimacy } \\
\text { claims and justification. } \\
\text { Objects and devices can } \\
\text { produce measures and } \\
\text { comparisons. Yet, time and } \\
\text { embodiment are not really } \\
\text { 'part of the story'. }\end{array}$ & $\begin{array}{l}\text { Space and time are co- } \\
\text { produced by the } \\
\text { legitimation process. They } \\
\text { are the shared, common } \\
\text { world made of emotions } \\
\text { and affects produced by the } \\
\text { narration. Things are not } \\
\text { legitimated or emerge and } \\
\text { are then legitimated. They } \\
\text { simply emerge 'obviously'. }\end{array}$ \\
\hline $\begin{array}{l}\text { Conceptual } \\
\text { focus }\end{array}$ & $\begin{array}{l}\text { Cognition; discourses; social } \\
\text { judgements; practices }\end{array}$ & $\begin{array}{l}\text { Practices; common worlds; } \\
\text { materiality; justification; } \\
\text { space }\end{array}$ & $\begin{array}{l}\text { Practices; Emotions and } \\
\text { emotional energy; affects; } \\
\text { embodiment; space; time; } \\
\text { narration }\end{array}$ \\
\hline $\begin{array}{l}\text { Philosophical } \\
\text { underpinnings }\end{array}$ & $\begin{array}{l}\text { Weber (1978); DiMaggio } \\
\text { and Powell (1983) }\end{array}$ & $\begin{array}{l}\text { Alford and Friedland } \\
\text { (1991); Boltanski and } \\
\text { Thévenot (1991); Lefebvre } \\
\text { (1991) }\end{array}$ & $\begin{array}{l}\text { Merleau-Ponty }(1945,1961 \text {, } \\
\text { 2003); Heiddeger (1962); } \\
\text { Ricoeur (1983) }\end{array}$ \\
\hline $\begin{array}{l}\text { Examples in } \\
\text { the MOS } \\
\text { literature }\end{array}$ & $\begin{array}{l}\text { Zimmerman and Zeitz } \\
\text { (2002); Bitektine (2011) }\end{array}$ & $\begin{array}{l}\text { Proffitt and Zahn (2006); } \\
\text { De Vaujany and Vaast } \\
\text { (2014) }\end{array}$ & $\begin{array}{l}\text { Voronov and Vince (2012); } \\
\text { Dale and Latham (2015); } \\
\text { Granqvist and Gustafsson } \\
\text { (2016); Pittz et al. (2017); } \\
\text { Friedland (2018) }\end{array}$ \\
\hline
\end{tabular}

Table 1: Three ontologies about legitimation process in the institutional literature

The ontologies of sculpture and bubbles both attempt to overcome traditional views of legitimacy and legitimation. While the former is already coherent with most institutional analysis regarding the process of social judgement involved in legitimation (as partly discursive), the latter requires some new ontological explorations (around the process and sociomaterial nature of legitimation). Drawing on the work of Merleau-Ponty $(1942,1945,1965)$ and related phenomenologies (Heidegger, 1962; Schatzki, 2010), this chapter sets out to explore further the ontology of bubbles. 
In a first time, I will come back to the neo-institutional literature and how it conceptualizes legitimacy and legitimation in the context of the ontology of discourse. It appears that legitimation is mainly theorized as a discursive, judgmental and ideational process. Then, I will describe the ontology of sculpture. I will detail the Marxist underpinnings (e.g. Marxist phenomenology) I see behind these dichotomist views of the process of social judgement corresponding to legitimation and the evolution of organizational space. Legitimation appears here as both a discursive and material set of activities (appropriation, re-appropriation and de-appropriation of space). I will illustrate the ontology of sculpture through a case narrative about a former NATO building transformed into a university. Then, I will develop the ontology of bubbles, which departs radically from a discursive and judgmental view of legitimation. This ontology emphasizes jointly the importance of bodies, materiality, spatiality and temporality in the legitimation process. The emotional flow involves both sensations and various material mediations (e.g. gestures, movements, faces, instruments, colours, etc.), which produce a specific space-time, a 'here and now'. The emergence of objects and their legitimation are not separated anymore in space and time (which is still the case in the two other ontologies). There is at best a deeper sedimentation of some practices, more or less exclusively pre-reflexive at some points. This view will be illustrated through a case narrative about the legitimation of activities in and around a makerspace in Paris. I will conclude this chapter on a systematic comparison and discussion of the two post-discursive ontologies, namely the ontology of sculpture and the ontology of bubbles.

\section{Legitimation as a discursive and judgmental process in the neo-institutional literature}

\subsection{From legitimacy to legitimation}

Legitimacy is a core philosophical and sociological concept. It is grounded into Max Weber's (1978) work on the legitimacy and sources of authority. The key questions are: what will make people obey other people? What are the deep underpinnings of authority? As reminded by Friedland (2018: 517), Weber's thought includes an emotional component; 'Max Weber analysed value rationality as an 
emotional state. Value rationality has a conceptual affinity to "affectual" action, action determined by "the actor's specific affects and feeling states" (...), one of Weber's four types of social action. Each — value and affect—is done "for its own sake," the difference between them located in the former's "self-conscious formulation" and its "planned orientation" (Weber, 1978, p. 25)'. For Weber, values are not simply valid ideas, but value feelings. In addition, Weber's thought was subtly historical, capturing a major shift towards rationality and rational-thinking, a move towards 'colder' emotions and relationship with the world. Nonetheless, emotions remained more a state and a dimension to explore the sources of legitimacy than a process constitutive of the obviousness of authority (see e.g. Merleau-Ponty, 1945; Arnasson, 1993).

Beyond Max Weber and the field of sociology, MOS have changed the focus of legitimacy-oriented studies. Organizations, and the products or services they provide, are now part of the scope of legitimacy. Collective activity can be more or less legitimate, in particular its organization and the resources it gathers. How organizations acquire and maintain their legitimacy in complex and changing institutional contexts has been a significant topic in institutional theory (e.g. Meyer and Rowan 1977; DiMaggio and Powell 1983; Elsbach 1994; Scott 1995; Lounsbury and Glynn 2001; Suddaby and Greenwood 2005). Organizational legitimacy thus corresponds to 'a generalized perception or assumption that the actions of an entity are desirable, proper, or appropriate within some socially constructed system of norms, values, beliefs, and definitions' (Suchman, 1995: 574).

Suchman (1995) has provided a major summary of perspectives about organizational legitimacy, putting forward, among others, a distinction between cognitive, normative/social and pragmatic legitimacy. Legitimacy can thus be the taken for grantedness of a situation (cognitive legitimacy), its unquestionable and compelling power (normative legitimacy), or a necessary instrumental way to act (pragmatic legitimacy). Legitimacy (in particular normative legitimacy) is grounded in a context in which individual behaviours, patterns of collective behaviours and artefacts involved in behaviours are meaningful in a particular way. This context is the broader institutional or organizational field (DiMaggio and Powell, 1983). A field is a set of codes, rules and actors defining capital, reputation and prestige. Some behaviours, if adopted by legitimate people (in view of the rules of the field) and in 
a legitimate manner, will be judged as legitimate by external stakeholders observing them (competitors, customers, etc.). In addition, the field itself will exert normative, mimetic and coercive pressures favouring isomorphism (DiMaggio and Powell, 1983). In order to be part of the field and to be potentially identified as 'good', 'dominant', 'innovative' or 'prestigious', individuals and collective entities will have to look somewhat similar and, for instance, adopt partly identical structures and technologies.

In the early nineties, different streams of research suggested to go beyond field-based views of legitimacy to stick more closely to legitimation. Two linguistic fields (American neo-institutionalism and French pragmatism) have thus co-elaborated two different theoretical perspectives on legitimation processes that share numerous communalities: sociology of justification (Boltanski and Thévenot, 1991) and institutional logics (Friedland and Alford, 1991). If the former is grounded into a form of French pragmatism, the latter still draws on typical assumptions of neo-institutional debates.

For Boltanski and Thévenot (1991), our everyday work of justification is based on a closed set of 'worlds' with their own criteria, principles and metaphors. Justificatory work can borrow from one or several worlds that will have a legitimacy for their inhabitants. Sometimes, the work of justification can wrap different worlds or introduce inhabitants from different worlds that will lead to conflicts and particular modes of resolutions of these conflicts. Interestingly, the sociology of justification remains largely rhetorical (see recent attempts at introducing artefacts, materiality and space into the framework or to come back to material dimensions in the seminal work of Boltanski and Thévenot, 1991). Emotions are not really present in the seminal writings that are rather discursive and cognitive. Friedland (2018: 519) thus stresses that in the conventions of worth approach, Boltanski and Thévenot understand actors' critical capacities to agree about the goodness of common goods, to establish relations of equivalence through "things that count," as a "cognitive ability" or competence". Nonetheless, material agencies are present in the devices and measures likely to establish order (Gond, Demers and Michaud, 2017). 
Institutional logics are macro-level belief systems that shape actors' cognitions and actions at the field level (Friedland and Alford, 1991; Ocasio, 1997; Thornton, 2004). They connect institutions to the behaviour of organizations and their members (Thornton, 2004). Institutional logics correspond to 'organizing cognitive frameworks that provide social actors with 'rules of the game' (...) and that operate, often implicitly, as practical guides for action' (Jones et al., 2013: 52). Empirical research has shown that rather than a single dominant logic, oftentimes several competing logics exist at the field level (Lounsbury, 2007; Kraatz and Block, 2008; Reay and Hinings, 2009; Greenwood, et al., 2010; Jarzabkowski et al., 2013), as in the case of higher education (Gumport, 2000). Multiple logics may thus reside in parallel over long periods of time leading to competition, tensions and conflict between different forums drawing on different logics.

\subsection{Making sense of materiality, spatiality and temporality in legitimation processes}

It is increasingly acknowledged that logics include cognitive, normative, spatial and material dimensions (Thornton et al., 2012; Boxenbaum, Huault and Leca, 2016). The material dimension of logics has so far mostly been conceptualized as practices or structures rather than actual physical artefacts (Friedland and Alford, 1991). Scholars have only very recently acknowledged the need to attend to how materiality plays a role in sustaining or changing logics (Jones et al. 2013); 'At times, it appears as though institutional logics are located at the level of language [...] the ideal elements, on the other hand, appear to constitute the institutional logic' (Friedland, 2012: 589). Furthermore, how materiality is implicated with logics has rarely been explored. In a recent study, Monteiro and Nicolini (2015: 63) argue for the importance of including materiality in institutional analyses, suggesting that it will yield 'richer explanations [...] that are closer to the reality of social processes'. This processual perspective is likely to make sense jointly of the materiality, spatiality and temporality of legitimation.

Indeed, and before the debates about institutional logics and their dynamics, the idea of looking at legitimation or institutionalization as a process (not a 'state' or an 'entity') is not new (see Della Fave, 1986; Oliver, 1991; Stryker, 2000; Bitektine, 2011). But surprisingly, this has led to more longitudinal or historical views of processes (instead of an exploration of philosophies likely to make sense of the 
embodiment, materiality, movement and temporality at stake in legitimation processes) and discursive postures. Bitektine (2011) thus describes the 'process of legitimacy judgement formation'. Bitektine (2011: 159) identify fives stages in the process of legitimization: (1) Perception by an audience; (2) Classification (managerial versus technical legitimacy) and scrutiny (about the legitimacy type: consequential, procedural, structural, personal, linkage); (3) Analytical processing (cognitive judgement or socio-political judgement); (4) Benefit diffusion (inducement); (5) Compliance mechanisms (normative versus regulative legitimacy).

Fundamentally, three core elements are involved in the process of legitimacy judgement formation: 'the evaluating audience's perceptions of an organization or entire class of organizations (1), judgement/evaluation based on these perceptions (2), and behavioural response (acceptance, support, avoidance, sanctions, etc.) based on these judgements (3)' (Bitekine, 2011: 159-160). In that context, legitimacy is conceptualized as something that can be told, shared, computed and intellectualized. It remains quite symbolic and discursive. Spatiality and materiality are not relevant by themselves, until they are involved in the judgmental process of a human being: he/she judges, beyond sensations and feelings, with a transcendental capability.

In contrast, some scholars have recently emphasized the materiality (Jones, Boxenbaum and Anthony, 2013), spatiality (Profitt and Zahn, 2006) and historicity (de Vaujany and Vaast, 2014) of the process of legitimacy, particularly in contexts where organizational members draw on various institutional logics to legitimate their activities (Varländer, de Vaujany and Vaast, 2014). They suggest that it can judge as much as he or she judges, or that the judgment process involving a manager implies a lot of material mediations. Yet, embodiment, emotions and affects as key components of the process of legitimation are still put aside in explicit or implicit ontologies that remain largely discursive, cognitive and judgmental. This is an issue we will try to make more visible in the next section (focused on the ontology of sculptures) before detailing a possible alternative ontology that would depart more radically from discursive perspectives. 
2. The ontology of sculptures: Stressing the material and spatial dimensions of legitimation

2.1 A post-discursive vision of legitimation: a focus on activities of appropriation, reappropriation and de-appropriation of space

The relationship between space and legitimation has been recently explored by the institutional literature. At large, various discursive (i.e. story telling) and material (i.e. re-configuration or re-design of space) activities can help to better align organizational space and its connotations to the expectations of key stakeholders (Profitt and Zahn, 2006; de Vaujany and Vaast, 2014). This can be related to a threefold process. The first process is that of immediate discursive and material evolutions of organizational space through practices of appropriation, re-appropriation and de-appropriation ${ }^{2}$ that can be described the following way (see Figure 1 below):

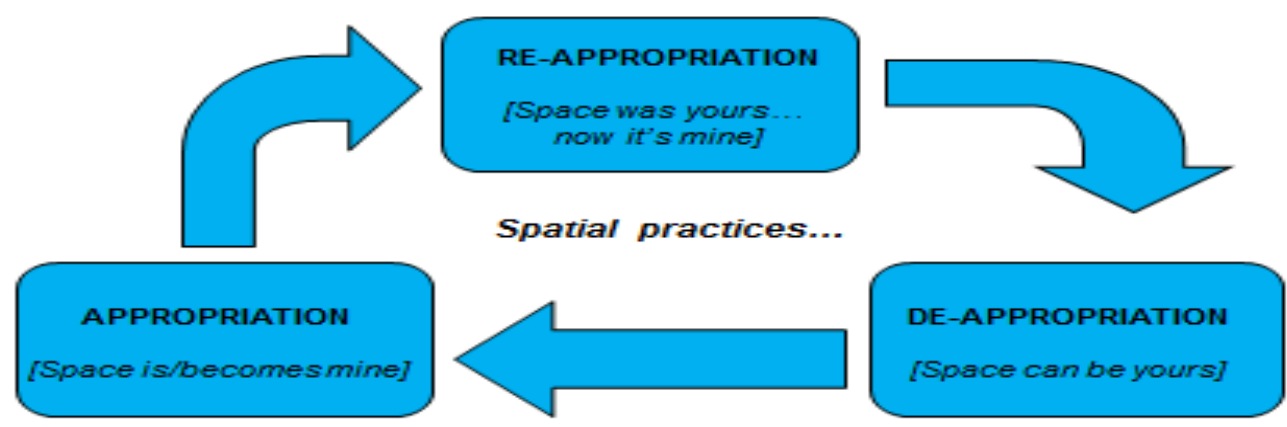

Figure 1: Three key spatial practices (From de Vaujany and Vaast, 2014).

\footnotetext{
${ }^{2}$ A practice which is close to home-staging activities in the context of the sale of an apartment. Owners are invited to clean the space and remove from it all personal belongings (to favor the projection of visitors into the space).
} 
The second process is the evolution of legitimacy claims grounded into this process. Communication practices can help produce deliberate legitimacy claims that can leverage (or not) the alignment between organizational space (as perceived by external stakeholders) and social expectations. The third and final process is the social judgement described by Bitektine (2011). It is the continuous judgement by specific stakeholders about the social acceptability of an organization, a set of organizational activities or some specific stakeholders of the organization. All three processes can be described the following way:

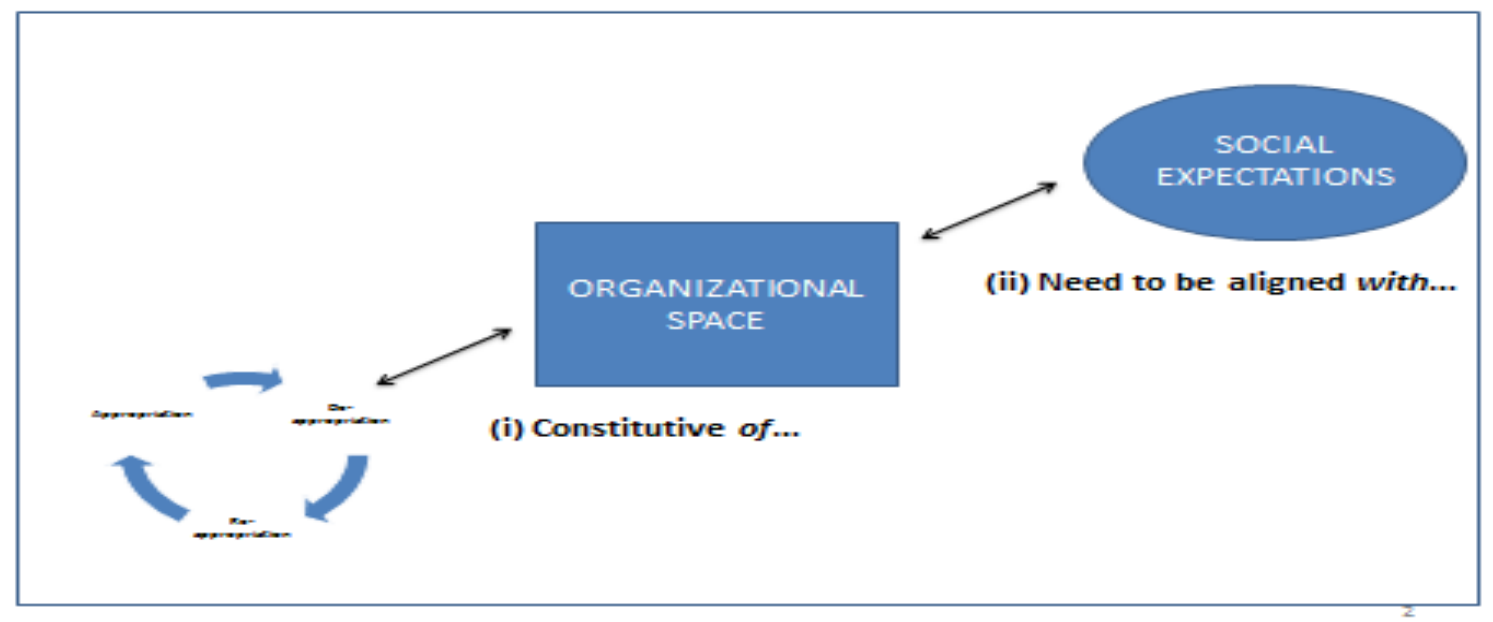

\section{Figure 2: Legitimation as a sculpture of organizational space through practices}

The sculpture can be more or less continuous and recursive, depending on the theoretical lens used to describe the spatial practices themselves. In line with Lefebvre's (1991) Marxist phenomenology, spatial practices are at the heart of the 'lived' space, the one experienced by individuals in the space of domination as 'conceived' by some dominant stakeholders and then 'perceived' by its inhabitants. To free themselves, individuals will circumvent some parts of the space, complete 'bricolage', and reappropriate the space in a way that will produce emancipation. Of course, this can be far from the legitimacy claims produced by dominant stakeholders. 


\subsection{An illustration of the ontology of sculpture}

De Vaujany and Vaast (2014) have used this ontology to explain the legitimation of a nascent university in Paris. This university re-used the former NATO headquarters (from 1959 to 1966) and was set up in October 1968. In short, the authors have identified two main phases. A first one (of reappropriation) during which the space has been largely kept as it is, and NATO memorabilia has been enacted so as to produce coherent legitimacy claims through the stars on the entrance grid (shown on the first leaflets), the NATO maxim (used in the first logo designed in 1971), the first teaching rooms (located in a set of two or three reshaped offices, which leveraged small group teaching and innovative pedagogy), the NATO former commandment room (re-used for executive and key meetings), etc. (see Figure 3 below). This connoted a prestigious and international setting that could be used to persuade bourgeois parents of the $16^{\text {th }}$ arrondissement of Paris. This was also used to legitimate an expected (for a French public university) selection of students. Compared to the students of another nascent university (University of Vincennes in the east of Paris), students of the University 'entered into

Dauphine' (and the former NATO 'fortress'), whereas Vincennes students simply 'went' to Vincennes. 

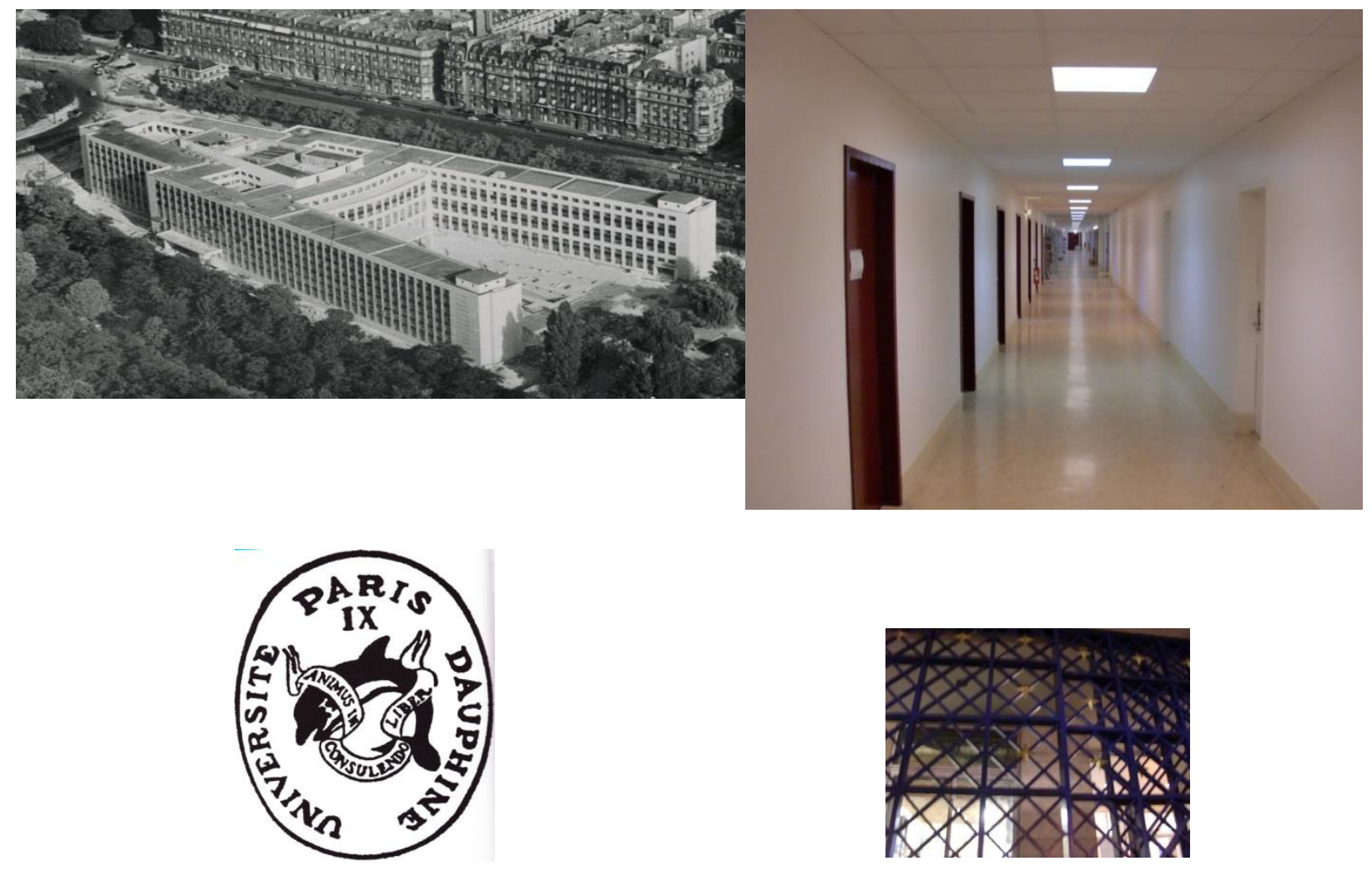

Figure 3: Views of important artefacts of the former NATO headquarters re-used by Paris-Dauphine university (Source: author's own photographs and Université ParisDauphine)

In the 1990s, the university started to renovate itself and gradually removed key NATO artefacts (deappropriation phase). The ground floor has been completely renovated, a new wing has been added, the former NATO commandment room has been completely redesigned, and recently, the main hall has been completely restructured in a more 'corporate' way. The search for executive students and corporate sponsors is now a key strategic stake. Legitimacy claims grounded into organizational space have thus evolved (de Vaujany and Vaast, 2014).

The ontology of sculpture assumes (dominant) external stakeholders judging the legitimacy of an organization, far from its collective activity. This view is not always relevant, in particular in the context of today's collaborative and crowd-based economy. Customers and shareholders are more and 
more included into 'users' experiences' (on-line experiences of the service, campus or corporate tours, beta-testing, open innovation, open strategies, etc.). Value co-creation processes involve all stakeholders recursively and continuously in the production of services. In some industries, the very distinction between consumers (or users) and producers collapse (Lin and Cornford, 2001; de Vaujany, 2006). All this makes it difficult to conceptualize an external stakeholder, judging the physical setting, the collective activity and its acceptability from afar ('outside'). This requires a new view of space and legitimacy locating legitimation within collective activity itself, and the embodied reflexivity of individuals' materially and discursively co-producing legitimacy more than they judge it.

\section{The ontology of bubbles: A radical departure from a judgmental view of legitimation}

\subsection{Key theoretical dimensions}

We develop here a different view of space and legitimacy, one that departs from the Marxist phenomenology developed by Lefebvre (1991) and that engages with an embodied connectivity as a way of moving from legitimacy in the eyes (and mind) of the beholder to legitimacy in the (moving) bodies of the people involved in a collective movement. This shift corresponds to a conception of sociality that is less sculpted by macro forces of logics, hegemonies and so on and ultimately more attuned to a world in which aggregates of micro-spheres border each other, with each sphere being a bubble bouncing off other bubbles constituting the social totality. To describe this ontology and grasp this complex embodied connectivity, we rely on two key authors, mainly Merleau-Ponty $(1942,1945$, 1964, 2003), but also Sloterdijk (2011), with whom the notion of bubble is contemporaneously associated. According to Merleau-Ponty (1942, 141-142): 'in a soap bubble, as in an organism, what happens in each point is determined by what happens in all others'. Through this, the interconnectivity of each intra and inter-individual experiences but also of the focus of experience is stressed (in particular in a world constituted by meaning and language). Merleau-Ponty sees structures as an object of perception rather than as constraints on perception. He also insists on the difference between 
biological, physical and social structures as part of experience. In other words, he often describes the sudden 'explosion' or collapse of perceptions in the contexts of sense-making processes (MerleauPonty, 1945). Likewise, Sloterdijk (2011) highlights spheres of aerial, bubble-centred experience and shared experience of life, extended and transformed through activities that are ultimately described spatially in an 'archeology of the intimate' making time something deeply constituted by everyday activities while often 'spatialized' for collective activities because of the reification and spatialization their materializations require.

I set to extend the bubble metaphor to some key aspects of experience as described by Merleau-Ponty. A soap bubble requires energy to exist and expand (and to blow). The bubble and its expansion give visibility to this energy. It is fragile and can easily explode (leaving a fluid and almost invisible trace of its past existence). In contrast to an opaque sphere, it is transparent and open to the world. It can melt into another bubble to constitute a bigger bubble. Most of all, being 'inside' (with a cognitive focus) does not prevent one from seeing what is 'outside'. Beyond the bubble one can always see and perceive other parts of the world and as the bubble bumps into other bubbles that randomly border it, our perceptions order this randomness into continuity, discontinuity, visibility and invisibilities.

To extend still the metaphor in another way, I will distinguish here three interrelated 'bubble units', three 'levels of being' as described by Merleau-Ponty from the self to collective activity': "there is an entire architecture, a complete 'tiering' of phenomena, a complete series of 'levels of being', which differentiate themselves through the enrolment of the visible and the universal over some visible where they are strengthened and inscribed (...) The Being is not in front of me, but it surrounds me, and in a way it goes through me. My view of Being does not come from elsewhere, but from the middle of the Being, the so-called facts, spatio-temporal individuals, are weighted through axes, pivots, and the dimensions or generality of my body are already embedded into these joints.' (Merleau-Ponty, 1964: 151).

\footnotetext{
${ }^{3}$ This view is also coherent with the spatial and immunologic project proposed by Sloterdijk (2011) that moves from the discovery of the self (bubble) to the exploration of the world (globe) to the poetics of plurality (foam).
} 
The first bubble unit will be being itself in the world, the second bubble unit, being in acting with others, the third being in being with others. The move from the first to the third level of being describes a move from an isolated individual to a more socialized and finalized world, bursting with human and non-human agencies constituted through activity. Of course, each level cannot be separated from the others, and gains visibility in activities that include all levels in the same movement.

The first 'bubble unit' is deeply cognitive, lonesome and 'immobile'. It is grounded into the 'corps propre' (proper body) and the 'schéma corporel' (corporeal scheme) described by Merleau-Ponty (1945). People do not perceive external signals produced by artefacts they encounter. They actively constitute their immediate environment through assimilated structures of behaviours quickly (unconsciously) activated and deeply embodied (far from any view of mental thoughts adjusting and transmitting orders to a body). In a way, the body and the feeling of what it is, and how it continuously mediates our relationship with the world (corporeal scheme ${ }^{4}$ ) constitute a sensorial bubble which is both the inside and outside of perception. This bubble is a continuous present. Indeed, in our perceptions "there is no anteriority, there is simultaneity and even delay" (Merleau-Ponty, 1964, 162).

An individual will not hear all of the surrounding noises, not see everything and not be attentive to all feelings in one's body. One will actively select one's visible and tangible world through one's lived body. Individuals will continuously recreate new bubbles. And should one bubble blow up, another one can immediately replace it, such that there is never 'ontological emptiness' in perception. All this will result in particular relationships with the environment and space. As interpreted by Giddens $(1984,65)$, 'the body, Merleau-Ponty points out, does not 'occupy' time-space in exactly the same sense as material objects do. As he puts it, "the outline of my body is a boundary which ordinary spatial relations do not cross.' This is because the body, and the experience of bodily movement, is the center of form of action and awareness, which really define its unity. The time-space relations of

\footnotetext{
${ }^{4}$ 'Likewise, my all body is not for me an assemblage of organs superimposed in space. I see it in an indivisible situation, and I know the position of each of my members through a corporeal schema into which they are folded' (Merleau-Ponty, 1945: 127). This corporeal scheme is also close to what philosophers or sociologists call agency: '[corporeal scheme is also an agency] (...) my body appears to me as a posture in view of some actual or possible tasks. Indeed, its spatiality is not like those of external objects or that of 'spatial sensations', a spatiality of position, but it is a spatiality of situation' (Ibid: 129).
} 
presence, centered upon the body, are geared not into a 'spatiality of position', in Merleau-Ponty's words, but a 'spatiality of situation'. The 'here' of the body refers not to a determinate series of coordinates but to the situation of the active body towards its tasks.' .

Depending on emotions and sensations, the bubble will expand or not (to cover a broader space), explode or not (if emotions become too extreme). The bubble will also be constitutive of that invisibility which makes action possible (Merleau-Ponty, 1964, 2003), an invisibility that is not the opposite of visibility (Merleau-Ponty, 1964). It is simply the inactivated, circumvented and other side of the bubble. While it could be physically possible sometimes to 'see' what is bordering the bubble (as it is transparent), most people will not do it, or will be in a mood in which they do not need to do $\mathrm{so}^{5}$. Being in a bubble has a recursive and reflexive legitimacy of its own design. Finally, MerleauPonty (1945) provides a phenomenological critique of 'judgment' at the level of being (which will be particularly crucial for our deconstruction of legitimacy). Judgment is not an intellectual move beyond sensations and feelings and Merleau-Ponty (1945: 56) is sceptical about intellectualist theses defending this view: 'Judgement is often introduced by what is missing from sensations in order to make possible a perception. A sensation is not supposed to be a real element of consciousness (...) Intellectualism lives from the refutation of empiricism and judgment has often had the function to cancel the possible dispersion of sensations. Reflexive analysis is established by pushing realist and empiricist theses to their end-point, and by showing through absurdity the anti-thesis'.

Merleau-Ponty defends a more experiential view of judgment ${ }^{6}$, which is embodied and always interconnected (to things and other people's experience). He states: "Between sensations and judgement, common experience makes a clear distinction. Judgment is for that a stance, it aims at knowing something valuable for my-self at all times of my life and for the other existing or possible

\footnotetext{
${ }^{5}$ Merleau-Ponty (1964) uses the example of walking and seeing the back of someone. Her face is invisible. But our perception extrapolates it. If I think I know the person, I can call her, and expect her face and her voice to occur. Invisibility is not the opposite of visibility, it is more the continuity of it, a condition of possibility of our perception, experience and agency.

${ }^{6}$ At the opposite of the scientific construction of facts: 'When I engage my body among the things, they co-exist with me as incarnated subject, and this life in things has nothing in common with the construction of scientific objects. Likewise, I do not understand other people's gestures through an act of intellectual interpretation, the communication of consciousness are not grounded into the common sense of their experiences, but they underpin it anyway (...)' (Merleau-Ponty, 1945: 226).
} 
spirits; sensation, conversely, is subject to appearance. It is beyond possession and any search for truth. This distinction vanishes in the context of intellectualism, as judgment is everywhere where pure feeling is not, which means everywhere" (Merleau-Ponty, 1945, 158).

Through individual movement, the bubble will be intertwined in space and time with traces of the bubble, or other individuals' bubbles. The individual decision to leave my office to reach another room for a meeting links me, provisionally and transitionally ${ }^{7}$, to a collective dance I need to share and adapt to. This corresponds to our second 'bubble unit'. It is related to movement itself (both material and physical), e.g. the practice of walking.

The last 'bubble unit' or 'level of being' deals more systematically with collective activity and the deep and stable interconnectedness of experience it favours. It is a way to emphasize phenomenologically the duration of collective activity. Time and space are constitutive and constituted by collective activity (Merleau-Ponty, 1945, 1964). Present time (a notion Merleau-Ponty sees as necessary jointly collective and individual - it is not possible to live present time 'alone' and for oneself as prolonged experience of solitary confinement discloses) is activity itself, a key juncture of past and future activities that flow individually and collectively around it. Merleau-Ponty (1945: 481) argues that 'the surge of a new present does not provoke a collapse of the past and a jolt of the future, but the new present is a passage from a future to a present and from the former present to the past, it is in a single move that from one end to another time starts moving'.

Following Gosden (1994) and Schatzki (2010), we will also consider the 'systems of reference'. Basically, a system of reference is a network of actions conveying their own time and space. This concept is designed to highlight the interconnectedness of actions and events (see also Hernes (2014) on the issue of the relationships between events). Gosden's (1994) discussion emphasizes that time and space are dimensions of action networks; 'Space and time are not ... abstract qualities providing the medium of social action, but rather... dimensions created through...systems of references'

\footnotetext{
${ }^{7}$ We see here a key point of departure with the third level of being which involves more stabilized and finalized relationships with others I need to coordinate myself with. Here, I simply go through a world I do not need to transform or live with.
} 
(Schatzki, 2010: 40). From the perspective of collective activity, in particular that of a set of individuals and artefacts involved in the production of a service, various collective bubbles are involved (see Figure 4).

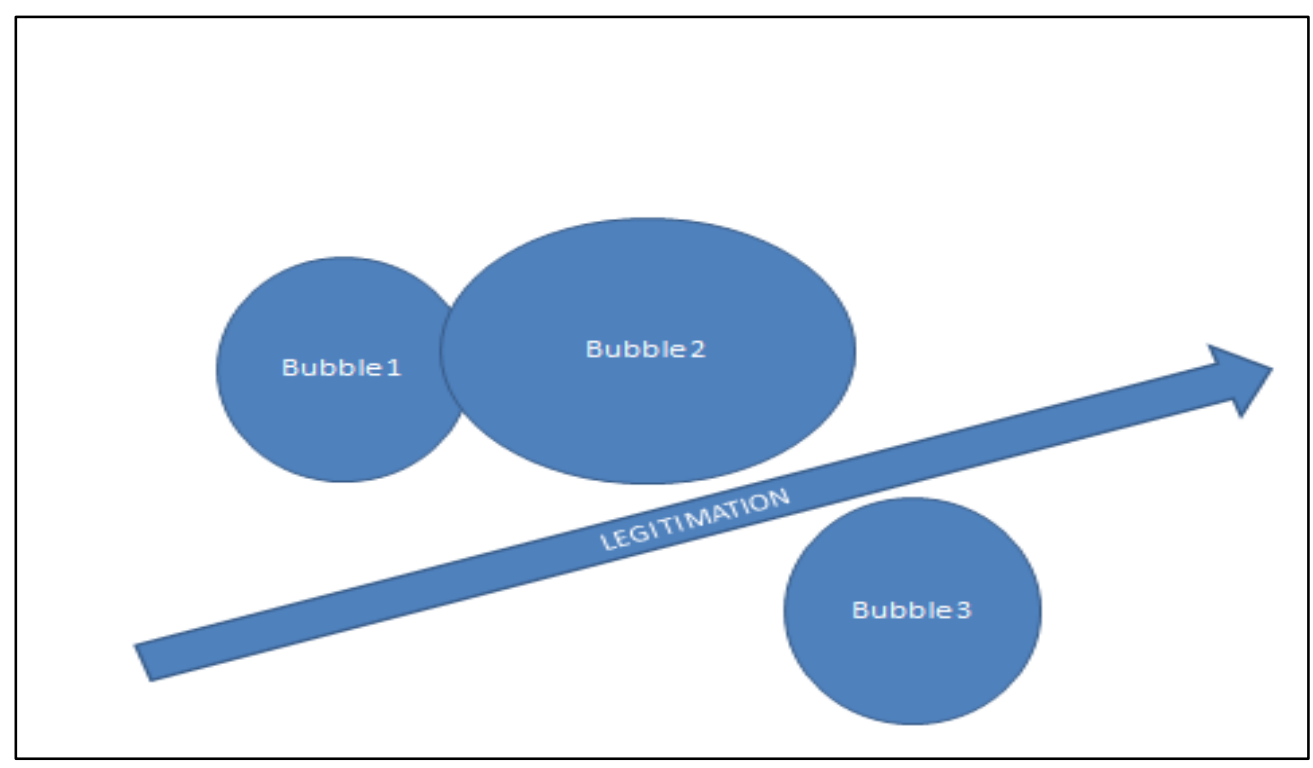

\section{Figure 4. Collective activity as a set of events, time-space bubbles}

Depending on the 'system of references' (Gosden, 1994), these bubbles will be completely independent (see bubble 3 in comparison to bubbles 1 and 2), or bordering and overlapping (see bubbles 1 and 2). Overlap will be harmonious or disharmonious, depending on the level of dyschrony (Alter, 2000, 2003). Indeed, temporal orientations (e.g. a present anchored in the past of nostalgia or a present focused on the anticipation of a future driven by anxiety) of the various collective activities at stake can be more or less conflicting. This can result in more or less conflicting, more or less shared perceptions and emotions about ongoing activities.

What about legitimation from the perspective of our three bubble units? We clearly depart here from a discursive and judgemental of authority and legitimacy (from one person to another, an external judgment and perception). Judgment becomes here an embodied co-valuation, the emergence of an unquestioned shared world in the flow of collective activity. People feel each other out and legitimation is always a shared feeling. There is no external third party mentally 'judging' a situation 
(as in the context of the process described by Bitektine (2011)) on the basis of legitimacy claims produced by the organization, whether intentionally or not. Legitimation is ultimately a deeply shared temporality, the ordering of a set of events at the heart of collective activity. It is related to the joint emergence or disappearance of 'institutions' in Merleau-Ponty's (2003) sense. For Merleau-Ponty (2003), an institution is a temporal phenomenon. It corresponds to all particular practices which will contribute to link events felt in the present. It is the broad set of temporal structures ordering the field of our experiences and all passivity-activities inside it. Some legitimations processes will be assimilated by this frame. Others will probably accommodate it. .

\subsection{An illustration of this post-judgmental view of legitimation}

Collaborative spaces (e.g. coworking spaces, maker spaces, fab lab and hacker spaces) have been blossoming since the early 2000s (Hatch, 2014; Lallement, 2015). A collaborative space is a place and space structured in such a way that it favours horizontal (between residents) and open collaborations (beyond the immediate involvement in an open space) between entrepreneurs and/or people managing innovative projects.

Whatever their location and configuration, collaborative spaces imply practices whose legitimacy is largely questioned. As any entrepreneurial project and structure (most collaborative spaces in Paris are less than three years old), these places need to demonstrate their acceptability to stakeholders who control resources they need (Lounsbury and Glynn, 2001; Zimmerman and Zeitz, 2002; Nagy, Rutherford and Lohrke, 2012). Their communitarian nature and their inclusive orientation (they host start up or emergent projects that also need to legitimate themselves) make them a particular organizational setting (Garrett, Spreitzer \& Bacevice, 2014; Lindtner, 2015). They need a twofold legitimation process, i.e. the legitimation of the place and that of the start-up it hosts, with possible synergies between the two.

Basically, collaborative spaces' legitimation is not obvious, both socially (acceptability) and cognitively. One key principle, value co-creation, is rather counter-intuitive. In continuation of digital business models (such as Blablacar or Uber), customers are actively involved in part or the totality of 
the service provided. In a way, they pay for a service they provide themselves, following the principles of a potluck where everyone brings along the food they wish to eat. The practice is definitely not recent: bars, nightclubs or restaurants involve the co-production of an atmosphere and some features of the service provided. Digital tools make it possible to perpetuate and exploit the community dimension of the process in various ways.

To illustrate these legitimacy stakes and beyond them, the third ontology about legitimation, we will dram from an ethnography of a specific type of collaborative space, a makerspace in Paris (see appendix for a summary of data collection). Collaborative spaces are interesting for the study of legitimacy and legitimation. Ultimately, they are young meta-organizations (Ahrne and Brunnson, 2008): young entrepreneurial structures hosting young entrepreneurial structures or individual projects.

TS is a very interesting place and space. It is bounded, iconic and very atypical. The place was set up in the east of Paris (not far from the train station 'Gare de Lyon') after a riot in front of an artistic squat. Dealers fought in front of the squat, and under the pressure of citizens, the mayor decided to take measures and experiment with new places subsidized by the city. TS opened in 2005 in a former power plant (which used to be a squat itself). It accepts professional and non-professional artists, and offers them several floors to practice their art. The ground floor is devoted to fashion designers, actors and coworkers. The second floor is opened to painters and sculptors. The third floor is dedicated to painters and photographers (with an argentic workshop). Finally, the fourth floor is aimed at novelists. TS also includes a fab lab.

Artistic squats are both a model and a counter-model for TS. Part of the structure of squats is reproduced, with a usher (ouvreur in French) at the entrance of the place, with a view on the street and of who is coming in and out. The usher is both a controller and a helper. One of the worst fears of the controllers and the manager is to see the place become a squat again. Thus, each resident has a physical member card that is left at the entrance. At the end of each day, there should be no cards in the rail behind the opener. Nobody is allowed to stay overnight. This would be likely to happen, as 
$60 \%$ of the residents are on income support (French RMI). Some people are thus in highly precarious situations (we heard a phone conversation of a member who did not know where he would spend the coming night).

The place also organizes trainings in management (e.g. a session about business models and another one about accounting). We could say that managers are stuck in the middle of three institutional logics (art, management, social involvement), and the search for horizontality and equality in the treatment of residents is at the heart of it. This is epitomized by the story of the coffee-machine. Since the beginning, coffee has been free within the space. It is a filter-based coffee. At some point, several residents asked for a better quality of coffee, in particular for their guests. They wanted a Nespresso machine. This resulted in intense debates. This coffee (not free anymore) would break the internal logic of the community (equality). It has thus been decided to put this second coffee machine far, at the entrance of the place.

Before detailing the narrative of our three bubbles units, it is important to give details about the body and the situation of the researcher involved in the organizational setting and joining the bubbles he observed. The researcher was mainly seated on the ground floor (in the coworking area). It was a great location to observe the entire floor and to see all the people coming in and out (as he was in front of the only entry point in the building). Sometimes, he went upstairs to work in the kitchen. This was an opportunity for a broader walk and to remain seated and to be at the core of the third bubble unit (lunch).

Let us now move more systematically into the three bubbles units we described in our theory section. Artists are in their individual artistic bubbles. Their schema corporeal is melted with the piece of art they are producing. Most of the time, nothing exists beyond this fragile moment. The activity is completely embodied. People and movement of the outside can or could be seen, the 'bubble' is transparent. Yet artists remain in the visibility of what they are doing. The level of focus of most artists we crossed was thus amazing. And most bubbles were immobile. Outside the time and space of surrounding society. We even saw some artists not leaving to eat during lunchtime, still focusing on 
what they were doing. Obviously, all this created a lot of invisibilities (Merleau-Ponty, 1964): that of the preparation and planning of the piece of art, that of the techniques behind simple gestures, that of the punctual discussions and help between residents. Interestingly, some bubbles were more influential and material than others. The noise of people in the fab lab and the use of some tools by sculptors could be disturbing. The smell of painting and the traces of paint could also disturb the bubble of the others.

The second bubble was a more mobile one. Clearly, walking around was a key exercise. It started with the entrance into the building. The usher at the entrance, the very iconic dress workshop on the ground floor, the familiar people to whom one needs to greet... Sometimes, walking was a way to apparently explode the bubble. Someone stopped in front of a painting to comment on it and ask questions. We say 'apparently', as often, between regular artists, this was more a way to make the project and what is going on explicit than to really break the dynamic. Quickly after the conversation, the bubble was recreated. Moving bubbles were clearly a way to bigger collective bubbles. Lunchtime, more or less shared (inside and outside) by residents, is an opportunity to 'join', 'reach' and 'move to' a different bubble. The first mainly individual bubble is left behind. At this point in time, it is provisionally broken. Another time and space, more related to the general shared rhythm of the place and society at large, are joined. Walking makes visible the fact that this time and space have always been there, potentially visible, necessarily made invisible to make the activity of artists possible. Interestingly, movement and co-movements at the level of these evanescent mobile individual bubbles are at the heart of what could be seen as legitimation. In particular, this is in the time and space of this shared movement that legitimacy will be at stake and legitimation will move further or not. A strange scene we witnessed epitomized this. A serigrapher, located on the ground floor, has been living through a tough period for several months. It had become almost impossible for him to sell his cards and posters. One day, we saw three interns from the dressmaker workshop (on the same floor) coming close to him to cut pieces of fabrics. Suddenly, we saw him activating, standing up, moving to his big printers and producing a set of posters. Will he sell them? Probably not. Will he learn or test something through this process? Probably not. But this is obviously not what was at stake. What was at stake for him was 
to share a legitimate movement, dancing with the others. Legitimation is an embodied and shared movement. It is not the result of an external social judgement (as described by Bitektine, 2011). It is an endogenous process, a co-construction, a co-valuation, a shared-feeling between the serigrapher and the three interns. Something they feel together, or rather, the serigrapher feels they share together as the three girls are part of the dance and pursue it.

Interestingly, neighbours and external stakeholders are also part of the more general dance and movement, the moving bubbles. From their perspective, this hermetic building and façade is only a mysterious space into which people come in and out. They do not see or feel the individual bubbles of level 1 . They see only a set of successive individual movements. They do not understand why people do not have lunch in their restaurants or share their activities (for associations). The dance is just a force they do not share, an illegitimate music that is not part of the broader music of the area.

The last bubble unit is a way to move to what we see afterward as the 'system of references' (Gosden, 1993) of the place, the human activities deeply at stake in it. In relationship with our observations in the context of TS, we observed four main collective bubbles that are part of the shared 'system of references'. They constitute 'events', specific durations (Deroy, 2008; Schatzki, 2010; Deroy and Clegg, 2011; Hernes, 2014; Hussenot and Missonier, 2016) and expressions (de Vaujany, 2017): individual artistic projects (1), floors' collaborations (2), training sessions (3), lunchtime (4).

Individual projects are focused on the 'oeuvre', its space and temporality. Both can overcome the boundaries of TS. Floors' collaborations are episodic and more or less improvised (by chance encounter, immediate questions to a neighbour, etc.). Training sessions take place on the ground floor around circular tables. They last a couple of hours and follow an academic logic. They are clearly bounded in time and space and mainly involve external people to the space and its temporal dynamic. Lunchtime is a space and time of convergence, the most communal bubble for the residents of TS. Interestingly, these bubbles clash sometimes, making dyschronies (Alter, 2000; de Vaujany, 2006; de Vaujany et al., 2018) stronger. People in the dressmaking workshop can be disturbed by the noise and movements of those involved in training. Collaboration and its noise can be distracting and break the 
bubbles of others. And more simply, artistic activities can be harmful (because of the smell, the dirty traces, and the noise of some tools, etc.) for immediate neighbours. For the temporal and spatial cohabitation of all human activities, multiple mediations are necessary in particular to build a paradoxical legitimation of these punctual disharmonies. The manager of the place and multiple posters displayed in the space describe rules for the storage of wet paintings and the cleaning of the place. Events (on the ground floor) are a way to know each other better and meet people from other worlds.

In contrast to TS, other research I have been involved in (about collaborative spaces' tours) has been an opportunity to identify much more 'scenarized' and deliberate 'bubbles' cantered on a guide (who mainly guided the embodied attention of the group

Interestingly, the collective movement of people and the narration built around it can be a way to reconcile potentially conflicting institutional logics. In a context of institutional complexity with multiple logics (Friedland and Alford, 1991; Kraatz and Block, 2008), which impose conflicting demands and pressures on organizations and their members (Greenwood et al., 2010; Jarzabkowski et al., 2013), walking was a way for organizational members to invoke artefacts and narratives to mobilize and emphasize the compliance with particular logics.

\section{Discussion: back to our two post-discursive ontologies about legitimation}

In short, we can summarize our two post-discursive ontologies of legitimation in the following way:

\begin{tabular}{|c|c|c|}
\hline & $\begin{array}{l}\text { ONTOLOGY OF } \\
\text { SCULPTURE }\end{array}$ & $\begin{array}{l}\text { ONTOLOGY OF } \\
\text { BUBBLES }\end{array}$ \\
\hline Key focus & $\begin{array}{l}\text { Communication, justificatory } \\
\text { work, legitimacy claims }\end{array}$ & Shared experience, event, expression, narratives \\
\hline $\begin{array}{l}\text { Relationship } \\
\text { with space }\end{array}$ & $\begin{array}{l}\text { Space is there, constituted by } \\
\text { previous activities. Place is a } \\
\text { location }\end{array}$ & $\begin{array}{l}\text { Time and space are co-constituted through } \\
\text { teleological activities }\end{array}$ \\
\hline
\end{tabular}




\begin{tabular}{|l|l|l|}
\hline $\begin{array}{l}\text { Relationship } \\
\text { with time }\end{array}$ & $\begin{array}{l}\text { Linear time explored forward or } \\
\text { backward ('spatial legacies') }\end{array}$ & $\begin{array}{l}\text { Multiple times in the same experience, dyschronies } \\
\text { (shared, non-necessary harmonious events) }\end{array}$ \\
\hline $\begin{array}{l}\text { Status } \\
\text { legitimacy }\end{array}$ & $\begin{array}{l}\text { A process of social judgement } \\
\text { Roots }\end{array}$ & $\begin{array}{l}\text { A shared feeling of continuity in the collective } \\
\text { dance completed by the people and artefacts } \\
\text { involved in the movement }\end{array}$ \\
\hline \multicolumn{1}{|c|}{ phenomenology } & Phenomenology of Merleau-Ponty $(1945,1964)$ \\
\hline
\end{tabular}

\section{Table 2: Two ontologies to make sense of legitimation}

The two ontologies we detailed and illustrated each correspond to different phenomenological stances. The first (Marxist) one is mainly rooted in Lefebvre's (1991) triad and his vision of space as a stage on which domination and emancipation take place. Authority and legitimacy are obviously at stake every time. Organizational space needs to be re-invented continuously to win or balance the play. Most of all, Lefebvre is clearly versed into analytical dichotomies (e.g. between social and material or human versus material agencies). In continuation of a Marxist vision, he sees appropriation as a possible move from Nature, a transformation (resulting in something else). In contrast, the phenomenological vision of the second ontology (in particular from the perspective of Merleau-Ponty) is a way to depart from a priori dichotomies (e.g. between nature and culture, materiality and sociality, humanity and sociality) and develop a post-Marxist view of judgement. Each category needs the other to make sense of itself. Beyond that, it is always the invisibility created by the visibility of a perception the other faces. Most of all, this has very interesting implications for the conceptualization of legitimation. It is an exogenous judgement from the first perspective (someone is judging from the outside), while from the perspective of the second ontology, it is an endogenous process (people and their mediations feel something together).

What about the managerial implications of all this? Clearly, the first ontology, closer to common sense language and managerial practice, seems to have more potential (in particular for teaching activities). 
With a focus on the three spatial practices (of appropriation, re-appropriation and de-appropriation), one can play with space and its communication (legitimacy claims) to adjust space with social expectations. Nonetheless, it is far from a causalist view, as space is constituted by a large (and unpredictable) set of activities, and the final interpretations by a given actor (and his/her preference) remain impossible to anticipate at a point in time.

The potential added value of the second ontology is beyond something that could be said or thought. It is more at the level of doing and pre-reflexivity. The invitation to managers would be to continuously be part of the movement, and be immersed within their customers' or shareholders' experience (on line and off line) and then to elaborate emergent conditions of possibilities. If management is an $e x$ ante agency for the ontology of sculpture, it is more a transcendence in immanence (de Vaujany, Aroles and Laniray, 2018) for the ontology of bubbles. Actors need to produce contextualized conditions of visibilities and invisibilities, continuities and discontinuities in the flow of their activities and what they feel they do. Actors need to get an intimate sense of what is going on, to be continuously part of it, to be aware of potential ruptures in the collective dance, from the shared-point of view of people and objects dancing.

Lastly, we see several avenues for further research about the material, spatial and temporal dimensions of legitimation. The first would be to use the second ontology in the context of a multi-site, distributed organization (far from the controlled and mono-site context of TS). This is likely to introduce interesting spatial and temporal tensions in the collective dance. The second avenue could be a more systematic analysis of bodily movements inside and outside of buildings, combined with ethnography and semi-structured interviews. This could be a way to grasp both movement and reflexivity at stake in joint legitimation. The third would be the study of movement in historical context (as in the case narrative elaborated by de Vaujany and Vaast, 2014). This could be a way to understand how past (in particular institutionalized past through vestiges and ruins) can be involved in collective dance of legitimation. 


\section{References}

Allison, T. H., Davis, B. C., Short, J. C., \& Webb, J. W. (2015). Crowdfunding in a prosocial microlending environment: Examining the role of intrinsic versus extrinsic cues. Entrepreneurship Theory and Practice, 39(1), 53-73.

Alter, N. (2000). La logique de l'innovation ordinaire, Paris : PUF.

Alter, N. (2003). Mouvement et dyschronies dans les organisations. L'Année sociologique, 53(2), 489514.

Arnason, J. P. (1993). Merleau-Ponty and Max Weber: An Unfinished Dialogue. Thesis Eleven, 36(1), $82-98$.

Ashforth, B.E. and Gibbs, B.W. (1990). The Double-Edge of Organizational Legitimation. Organization Science, 1(2), 177-194.

Augoyard, J. F. (1979). Pas à pas: essai sur le cheminement quotidien en milieu urbain. Paris: Editions du Seuil.

Bensman, J. (1979). Max Weber's concept of legitimacy: an evaluation, in Vidich, A.J. and Glassman, R. (Eds). Conflict and Control: Challenges to Legitimacy of Modern Governments, Beverly Hills: Sage Publications, pp. 17-48.

Bitektine, A. (2011). Toward a theory of social judgments of organizations: The case of legitimacy, reputation, and status. Academy of Management Review, 36(1), 151-179.

Boltanski, L. \& Thévenot, L. (1991). De la justification: les économies de la grandeur, Paris: Gallimard.

Boltanski L. et Chiapello E. (1999). Le nouvel esprit du capitalisme, Paris : Gallimard.

Bouncken, R. B., Komorek, M., \& Kraus, S. (2015). Crowdfunding: The current state of research. The International Business \& Economics Research Journal (Online), 14(3), 407.

Boxenbaum, E., Huault, I. \& Leca, B. (2016). Le tournant matériel dans la théorie néoinstitutionnaliste, in de Vaujany, FX., Hussenot, A. \& Chanlat, JF. (eds). Théories des organisations, Paris : Economica.

Dale, K., \& Latham, Y. (2015). Ethics and entangled embodiment: Bodies-materialities-organization. Organization, 22(2), 166-182.

Deephouse, D. L. (1996). Does isomorphism legitimate? Academy of management journal, 39(4), 1024-1039.

Deroy, X. (2008). L'événement entrepreneurial et le modèle entrepreneurial. Revue française de gestion, (7), pp. 51-63.

Deroy, X., \& Clegg, S. (2011). When events interact with business ethics. Organization, 18(5), pp. 637-653. 
de Vaujany, F.X. (2006) "Entre éternité et actualité : la difficile co-évolution des champs de la communication au Vatican," Communications of the Association for Information Systems: Vol. 18 , Article 17, available at: http://aisel.aisnet.org/cais/vol18/iss1/17

de Vaujany, F. X. (2017). Pour un management paradoxal de nos pratiques de recherche-Invitation à un voyage immobile avec Merleau-Ponty. Revue Française de Gestion, 43(268), 11-39.

de Vaujany, FX. \& Vaast, E. (2014). If these walls could talk: The mutual construction of organizational space and legitimacy. Organization Science, 25(3), pp. 713-731.

de Vaujany, F. X., Fomin, V., Haefliger, S., \& Lyytinen, K. (2018). Rules, Practices and Information Technology (IT): A Trifecta of Organizational Regulation. Information Systems Research, forthcoming.

de Vaujany, FX., Aroles, J. and Laniray, P. (2018). Towards a Political Philosophy of Management: Performativity \& Visibility in Management Practices, Philosophy for Management, forthcoming.

de DiMaggio, P., \& Powell, W. W. (1983). The iron cage revisited: Collective rationality and institutional isomorphism in organizational fields. American Sociological Review, 48(2), 147-60.

Dowling, J., \& Pfeffer, J. (1975). Organizational legitimacy: Social values and organizational behavior. Pacific sociological review, pp. 122-136.

Elsbach, K. D. (1994). Managing organizational legitimacy in the California cattle industry: The construction and effectiveness of verbal accounts. Administrative science quarterly, 57-88.

Emirbayer, M., \& Mische, A. (1998). What is agency? American journal of sociology, 103(4), pp. 962-1023.

Della Fave, L. R. (1986). Toward an explication of the legitimation process. Social Forces, 65(2), 476500 .

Friedland, R. (2018). Moving institutional logics forward: Emotion and meaningful material practice. Organization Studies, 39(4), 515-542.

Friedland, R. \& Alford, R.R. (1991). Bringing society back in: Symbols, practices, and institutional contradictions, In, W.W. Powell \& P.J. DiMaggio (eds.), The New Institutionalism in Organizational Analysis, pp. 232-263. Chicago: University of Chicago Press.

Goodrick, E., \& Reay, T. (2011). Constellations of Institutional Logics Changes in the Professional Work of Pharmacists. Work and Occupations, 38(3), 372-416.

Gosden, C. (1994). Social being and time, Wiley.

Garrett, L. E., Spreitzer, G. M., \& Bacevice, P. (2014). Co-constructing a Sense of Community at Work: The Emergence of Community in Coworking Spaces. Academy of Management Proceedings (Vol. 2014, No. 1, p. 14004).

Giddens, A. (1984). The constitution of society: Outline of the theory of structuration. Univ of California Press. 
Gond, J. P., Demers, C., \& Michaud, V. (2017). Managing Normative Tensions within and across Organizations. The Oxford Handbook of Organizational Paradox, 239.

Granqvist, N., \& Gustafsson, R. (2016). Temporal institutional work. Academy of Management Journal, 59(3), 1009-1035.

Greenwood, R., Díaz, A. M., Li, S. X., \& Lorente, J. C. (2010). The multiplicity of institutional logics and the heterogeneity of organizational responses. Organization Science, 21(2), 521-539.

Gumport, P. J. (2000). Academic restructuring: Organizational change and institutional imperatives. Higher education, 39(1), 67-91.

Halford, S. (2005). Hybrid workspace: Re-spatialisations of work, organisation and management. New Technology, Work and Employment, 20, 19-33.

Hatch, M. (2014). The maker movement manifesto. McGraw-Hill Education.

Hayles, N. K. (2008). How we became posthuman: Virtual bodies in cybernetics, literature, and informatics. University of Chicago Press.

Heidegger, M. (1927, 1962). Being and time, trans. J. Macquarrie and E. Robinson, Sunny Press.

Hernes, T. (2014). A process theory of organization. OUP Oxford.

Hussenot, A., \& Missonier, S. (2016). Encompassing Stability and Novelty in Organization Studies: An Events-based Approach. Organization Studies, DOI: 10.1177/0170840615604497

Introna, L. D. (2018). On the Making of Sense in Sensemaking: Decentred Sensemaking in the Meshwork of Life. Organization Studies, 0170840618765579.

Jarzabkowski, P., Smets, M., Bednarek, R., Burke, G., \& Spee, P. (2013). Institutional ambidexterity: Leveraging institutional complexity in practice. Research in the Sociology of Organizations, 39, 3761.

Johnson, C., Dowd, T. J., \& Ridgeway, C. L. (2006). Legitimacy as a social process. Annual review of sociology, 53-78.

Jones, C., Boxenbaum, E., \& Anthony, C. (2013). The immateriality of material practices in institutional logics, Research in the Sociology of Organizations, 39, pp. 51-75.

Kallinikos, J. (2003). Work, human agency and organizational forms: an anatomy of fragmentation. Organization Studies, 24 (4), 595-618.

Kraatz, M. S., \& Block, E. S. (2008). Organizational implications of institutional pluralism. The Sage handbook of organizational institutionalism, 840, 243-275.

Lallement, M. (2015). L'âge du faire: hacking, travail, anarchie. Paris: Seuil.

Lefebvre, H. (1991). The production of space (Vol. 142). Blackwell: Oxford.

Lin, A., \& Cornford, T. (2000). Sociotechnical perspectives on emergence phenomena (pp. 51-60). Springer London. 
Lounsbury, M. (2007). A tale of two cities: Competing logics and practice variation in the professionalizing of mutual funds. Academy of Management Journal, 50(2), 289-307.

Lounsbury, M., \& Glynn, M. A. (2001). Cultural entrepreneurship: Stories, legitimacy, and the acquisition of resources. Strategic management journal, 22(6-7), 545-564.

Manning, S., \& Bejarano, T. A. (2017). Convincing the crowd: Entrepreneurial storytelling in crowdfunding campaigns. Strategic Organization, 15(2), 194-219.

Mead, G. H. (1932). The philosophy of the present, Prometheus Books

Merleau-Ponty, M. (1942). La structure du comportement. Paris : PUF.

Merleau-Ponty, M. (1945, 2013). Phénoménologie de la perception. Gallimard.

Merleau-Ponty, M. (1964). Le visible et l'invisible: suivi de notes de travail (Vol. 36). París: Gallimard.

Merleau-Ponty, M. (2003). L'institution, la passivité, Paris : Belin.

Meyer, J. W., \& Rowan, B. (1977). Institutionalized organizations: Formal structure as myth and ceremony. American journal of sociology, 340-363.

Modiano, P. (1999). Des inconnues. Paris: Gallimard.

Nagy, B. G., Pollack, J. M., Rutherford, M. W., \& Lohrke, F. T. (2012). The influence of entrepreneurs' credentials and impression management behaviors on perceptions of new venture legitimacy. Entrepreneurship Theory and Practice, 36(5), 941-965.

Ocasio, W. (1997). Towards an attention-based view of the firm. Psychology, 1, 403-404.

Oliver, C. (1991). Strategic responses to institutional processes. Academy of management review, 16(1), 145-179.

O'neil, M. (2014). Hacking Weber: legitimacy, critique, and trust in peer production. Information, Communication \& Society, 17(7), pp. 872-888.

Pittz, T. G., Boje, D. M., Intindola, M. L., \& Nicholson, S. (2017). 'COPE'ing with institutional pressures: a reintroduction of pragmatism to the study of organisations. International Journal of Management Concepts and Philosophy, 10(2), 113-129.

Proffitt W. \& Zahn G.L. (2006). Design, but align: The role of organizational physical space, architecture and design in communicating organisational legitimacy, in Clegg SR, Kornberger M (Eds) Space, Organizations and Management Theory, Copenhagen Business School Press, Copenhagen, pp. 204-220.

Reay, T., \& Hinings, C. R. (2009). Managing the rivalry of competing institutional logics. Organization studies, 30(6), 629-652.

Schatzki, T. R. (2010). The timespace of human activity: On performance, society, and history as indeterminate teleological events. Lexington Books.

Scott, W. R. (1995). Institutions and organizations (Vol. 2). Thousand Oaks, CA: Sage. 
Sloterdijk, P. (2011). Bubbles: Spheres, Volume I: Microspherology. Los Angeles, CA: Semiotext.

Stryker, R. (2000). Legitimacy processes as institutional politics: Implications for theory and research in the sociology of organizations. Research in the Sociology of Organizations, 17, 179-223.

Suchman, M. C. (1995). Managing legitimacy: Strategic and institutional approaches, Academy of management review, 20(3), pp. 571-610.

Suddaby, R. (2010). Challenges for institutional theory. Journal of Management Inquiry, 19(1), 14-20.

Suddaby, R., \& Greenwood, R. (2005). Rhetorical strategies of legitimacy. Administrative science quarterly, 50(1), 35-67.

Thornton, P. H. (2004). Markets from culture: Institutional logics and organizational decisions in higher education publishing. Stanford University Press.

Thornton, P. H., Ocasio, W., \& Lounsbury, M. (2012). The institutional logics perspective. John Wiley \& Sons, Inc..

Varländer, S., de Vaujany, FX. \& Vaast, E. (2014). Exploring the intersection between space, legitimacy and institutional logics: a study of campus tours", Workshop "Giving visual and material form to ideas, identity and imagination: architecture, urbanism and sustainable construction, Renate Meyer, Candace Jones, Silviya Svejenova and Eva Boxenbaum, VU, Vienna, Austria, 12th and 13rd May 2014.

Weber, M. (1978). Economy and society: An outline of interpretive sociology. Univ of California Press.

Zietsma, C., \& Toubiana, M. (2018). The valuable, the constitutive, and the energetic: Exploring the impact and importance of studying emotions and institutions. Organization Studies, 39(4), pp. pp. $427-443$

Zimmerman, M. A., \& Zeitz, G. J. (2002). "Beyond survival: Achieving new venture growth by building legitimacy". Academy of Management Review, 27(3), pp. 414-431. 


\section{APPENDIX: DATA COLLECTED FOR THE ILLUSTRATION \\ OF OUR TWO ONTOLOGIES}

\section{Data collected for the ethnography of universitas}

\begin{tabular}{|l|l|l|}
\hline \multicolumn{1}{|c|}{ Type of data } & \multicolumn{1}{|c|}{ Description } & Period of collection \\
\hline Participant-observations & $\begin{array}{l}\text { Five years of observations } \\
\text { (formalized in a memo) }\end{array}$ & $2009-2014$ \\
\hline Semi-structured interviews & $\begin{array}{l}5 \text { interviews (around 1.5 hours } \\
\text { each): 3 with senior emeritus } \\
\text { professors, 2 with senior } \\
\text { administrative staff (who had all } \\
\text { known the period of the 70s at } \\
\text { universitas) }\end{array}$ & $\begin{array}{l}\text { Centre d'archives du 20ème siècle } \\
\text { archives about the architect of } \\
\text { universitas) } \\
\text { Internal archives of the university }\end{array}$ \\
\hline Archives & $\begin{array}{l}\text { Websites, social medias, blogs } \\
\text { about the university and what is } \\
\text { going on in it. }\end{array}$ & \\
\hline On-line resources & $\begin{array}{l}\text { INA, videos on YouTube and } \\
\text { personal pictures (more than 4000) } \\
\text { about internal life. }\end{array}$ & $2010-2012$ \\
\hline Pictures and movies & \multicolumn{2}{|c|}{} \\
\hline
\end{tabular}

2. Data collected for the ethnography of TS

\begin{tabular}{|l|l|l|}
\hline Type of data & \multicolumn{1}{|c|}{ Description } & Period of collection \\
\hline Participant-observations & $\begin{array}{l}\text { 3 half-days of observations of the } \\
\text { external environment (cafés, } \\
\text { neighbourhood associations); } \\
9 \text { half-days of observations within } \\
\text { the maker space (in particular on } \\
\text { the first floor). } \\
\text { Observations were formalized by } \\
\text { means of a memo and an } \\
\text { observation guideline }\end{array}$ & \\
\hline Semi-structured interviews & $\begin{array}{l}\text { semi-structured interviews } \\
\text { (around 1 hour each): 2015 (January-July) } \\
\text { 2 with staff members } \\
\text { (general manager and } \\
\text { PR); }\end{array}$ & \\
\hline
\end{tabular}




\begin{tabular}{|l|l|l|}
\hline & $\begin{array}{l}- \\
\text { 2 with residents; } \\
\text { members with an old } \\
\text { local association, very } \\
\text { close to TS, and one with } \\
\text { a neighbour of TS } \\
\text { building }\end{array}$ & \multicolumn{1}{|c|}{} \\
\hline Archives & $\begin{array}{l}\text { Internal (status of TS, internal } \\
\text { rules, leaflets...) and external } \\
\text { (publications in journals and } \\
\text { magazines about TS) }\end{array}$ & 2015 \\
\hline On-line resources & $\begin{array}{l}\text { Netnography (Kozinets, 2005) of } \\
\text { blogs, social networks, websites, } \\
\text { forums about the environment, } \\
\text { artistic squats and the place } \\
\text { (TS)TS (rich) }\end{array}$ & \\
\hline Pictures and movies & $\begin{array}{l}500 \text { internal and external pictures } \\
\text { of the place and the area around } \\
\text { the place }\end{array}$ & 2015 (January-July) \\
\hline
\end{tabular}

3. Data treatment of universitas and TS: questions asked by the researchers to himself in the context of his observations and analysis of interviews and documents

3.1 Main focus of observations and reconstitutions of practices in the case of universitas [mainly inspired by Lefebvre, 1991]

a) Questions about key spatial practices to enter into and move in the space of universitas (relationship with practices of appropriation, re-appropriation and de-appropriation as physical, embodied activities)

- What do people do when they enter into the building? What did they do in the past (NATO/post-NATO period)? What are they expected to do/What where they expected to do while they entered into the space of universitas?

- What do people do while moving from one point of the building to another? What did they do in the past (NATO/post-NATO period)? What are they expected to do/What where they expected to do while moving from one point of the building to another (floors, wings)? 
b) Questions about work practices (relationship with practices of appropriation, reappropriation and de-appropriation as physical, embodied activities)

- What do people do in the context of classrooms and meeting rooms? What did they do in the past (NATO/post-NATO period)? What are they expected to do/What where they expected to do while working and communicating with each other?

c) Question about communications practices, how space or spatial practices are enacted in front of external visitors (relationship with practices of appropriation, re-appropriation and de-appropriation as symbolic, communicative activities)

- What do inhabitants do in front of external visitors (prospective students, potential sponsors, visiting scholars)? How is the space enacted and possibly reinvented in leaflets given to them, PPT presentations, and trajectories chosen inside the building? How do people appropriate, re-appropriate or de-appropriate space (clean it) to please them?

3.2 Main focus of observations and reconstitutions of practices in the case of TS [mainly inspired by Merleau-Ponty, 1945, 1964]

a) Questions about the way people feel in the space and time of TS activities, how they create, maintain and sometimes blow out the bubble of their creative activity (bubble 1)

- What are the continuities-discontinuities of the artistic or managerial activities within TS? What makes them start or stop?

- What are the visibilities-invisibilities of artistic activities within TS? For artist themselves and other artist or visitors looking closely at what they do and judging, commenting it?

- What are the postures, the immobilities and mobilities of artists in their immediate artistic bubbles (e.g. their posture in front of their paintings?)

b) Questions about the way people move in and across the space of TS (bubble 2)

- How do people move from one part of the building to another (rooms or floors)? Inside or outside the building? 
- How do people move from their immediate bubble of concentration to that of other people in the space? How do they enter into other people's space?

- How do people walk (slow/quick, careful/automatic walk, self-centered/open to the environment, direct/circumventing expected trajectories...)?

c) Questions about the way people outside the time and space of TS (e.g. immediate neighbours) feel and perceive the movement of TS members (e.g. in and out of the building (bubble 2)

- How are movements (inside or outside the time and space of TS) perceived by nonartists inside and outside the building?

d) Questions about how people move together and share a collective movement with other people and other artifacts inside the time and space of TS activities (bubble 3).

- How do people move together, what are the shared collective bubbled, the collective timespaces related to TS? The timespaces in and during which people feel obviously together, share a common space in a meaningful way, and common time. The outside is not really part of the process, nobody is expected to look and judge the collective activity which is not expected at all to depend on external resources. This timespace is self-satisfying.

NB: the exploration of these four questions led us to identify four key time and space in the embodied activities of TS members, particularly explicit at level 3 of our bubbles. 